\title{
A Few Important Landmarks in the Chinese Debates on Dialectical and Formal Logic ${ }^{1}$ from the 1930s
}

\author{
Jan VRHOVSKI
}

\begin{abstract}
With the rise of the discourse on dialectical materialism in the late 1920s, ideas related to the Marxist notion of dialectical logic started to circulate in the Chinese intellectual world. Not long after the first public discussions on dialectical materialism started to emerge in the early 1930s, the discussants on both sides started to address the question of the Marxist notion of logic and its relationship with Western formal logic. Consequently, over the 1930s, a series of separate public debates ensued, in which dialectical logic contended against the "conventional" forms of logic, such as traditional Aristotelian and modern formal logic. This paper outlines the major landmarks within the public as well as internal Marxist debates on logic in the 1930s. The discussion starts with a general overview of the intellectual background of the debates, and proceeds by analysing the principal developments in them, starting with Ye Qing's and Zhang Dongsun's polemic about "dynamic logic" from 1933, and concluding with the internal Marxist discussions on the sublation of formal logic in the last years of the decade.
\end{abstract}

Keywords: dialectical materialism, dialectical logic, formal logic, 1930s debates on logic, Republican China

\section{Nekaj pomembnih mejnikov v kitajskih razpravah o dialektični logiki iz tridesetih let 20. stoletja}

\section{Izvleček}

$\mathrm{Z}$ vzponom diskurza o dialektičnem materializmu v poznih dvajsetih letih 20. stoletja so ideje, povezane z marksističnim pojmom dialektične logike, pričele krožiti med kitajskimi izobraženci. Kmalu po vzniku prvih javnih razprav o dialektičnem materializmu v zgodnjih tridesetih letih 20. stoletja so udeleženci razprav na obeh straneh pričeli naslavljati vprašanja, povezana $\mathrm{z}$ marksističnim pojmom logike in njegovim odnosom $\mathrm{z}$ zahodno formalno logiko. Posledično je v tridesetih letih prišlo do razvoja več ločenih javnih razprav, v katerih

1 The author acknowledges the support of the Slovenian Research Agency (ARRS) in the scope of the research project N6-0161 (HUMEC) Humanism in Intercultural Perspective: Europe and China.

* Jan VRHOVSKI is a research fellow at University of Ljubljana, Slovenia. Email address: jan.vrhovski@ff.uni-lj.si

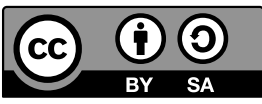


je pojem dialektične logike nastopil v nasprotju s tradicionalno aristoteljansko in moderno formalno logiko. V tem članku bom orisal osrednje mejnike tako javnih kot internih marksističnih razprav o logiki iz tridesetih let 20. stoletja. Pričujoča razprava se začenja s splošnim pregledom intelektualnega ozadja razprav ter se nadaljuje s podajanjem analize njihovih glavnih razvojnih smernic. Analitični del članka tako podaja pregled osnovnih vsebinskih segmentov razprav, od polemike med Ye Qingom in Zhang Dongsunom iz leta 1933 do razprav o sublaciji formalne logike $\mathrm{v}$ zadnjih letih istega desetletja.

Ključne besede: dialektični materializem, dialektična logika, formalna logika, razprave o logiki v tridesetih letih 20. stoletja, republikanska Kitajska

\section{Introduction}

Following the gradual introduction of classical works of dialectical materialism and dialectics of nature, in the late 1920s a general discourse on dialectical logic started to form, which in the years to come was shaped both by the Chinese adherents of dialectical materialism as well as proponents of other philosophical worldviews in China (see Tian 2019,149). At the initial stage, the discourse had been deeply immersed in the traditional Chinese world of ideas, poised between the classical philosophical concepts of complementarity, harmony, change, and so on one hand, and novel scientific, universalist systems of objectivity on the other (Rošker 2019, 204). With the subsequent introduction of more recent Soviet theories into Chinese Marxist discourse, which was heavily permeated with political ideas of class struggle and the notion of an unbridgeable distinction between idealism and materialism (Heubel 2019, 38), by the mid-1930s the discourse shifted onto an entirely different plane. ${ }^{2}$

While the textual and conceptual introduction of the Marxist philosophy of logic and mathematics started already in the mid- to late-1920s, the first extensive public debates

2 The article does not discuss the general discourse on logic in the above-mentioned period, but focuses only on the debates on dialectical logic in the 1930s. Although, in the 1930s, the discourse on dialectical logic also involved debates on the nature of formal logic, these did not represent the actual state of the science in the country. Furthermore, these debates did not overlap with the academic —at the time essentially philosophical—discourse on formal logic, yet were nevertheless partially dependent on it, in the sense that certain ideas about formal logic were extracted from the works of the members of Qinghua School of logic. The article further treats the development of the discourse on dialectical logic as a consequence of the establishment of dialectical materialism in Chinese intellectual circles, which were not directly connected to hose associated with other schools of logic. As such, the 1930s discourse on dialectical logic was, in the first place, a process of introduction and theoretical appropriation, which, in the case of its propagators, also indirectly involved a general idea of logic and dialectics prevalent among non-expert members of the intelligentsia. Finally, the manner in which the academic discourse on formal logic overlapped with the discourse on dialectical logic depended heavily on the participants' relationship with the former. 
started to ferment only at the beginning of the 1930s. The first major polemics related to dialectical logic broke out in the framework of broader debates on dialectical materialism, which, speaking more generally, developed between a group of philosophers led by Zhang Dongsun 張東荪 (1886-1973), on the one side, and Chinese adherents of Marxism headed by Ye Qing 葉青 (original name Ren Zhuoxuan 任卓宣, 18961990) on the other. The various discussions which developed in the course of the following decade (up to 1939), were extremely numerous and complex, with the participants addressing the question of dialectical logic at different stages of the debates. Over time, the arguments and sources adopted in the discussions also varied. If the debates in the early 1930s revolved around Plekhanov's notion of "dynamic logic", around 1935, when a second motion was promulgated in the framework of internal Marxist debates on dialectical logic by Li Da 李達 (1890-1966) and Ai Siqi 艾思奇 (original name Li Shengxuan 李生萱, 1910-1966), the focus of the debate shifted to the question of the overall relationship between formal and dialectical logic. Finally, between the years 1937 and 1939, a more scattered discussion on "sublation of formal logic" developed.

In the following discussion, I shall try to outline the main developments in the public and internal Marxist discussions on logic in the 1930s. Since, due to the broadness, wide scope and complexity of the discourse on logic in the focal decade, it would be impossible to convey a complete picture of the debates, I shall only focus on a few developments and contributions that are most relevant for the 1930s discussions on the Marxist notion of dialectical and formal logic. At the same time, the main aim of the following discussion will also be to provide considerable supplementations and, to a much lesser degree, corrections to the already existing contemporary survey on development of dialectical materialism in Republican China. Moreover, the following overview will represent one of the first surveys focusing on the debates on dialectical logic in Chinese 1930s in the Western sinological discourse. ${ }^{3}$

3 In Chinese, the earliest systematic overview focusing on the criticism and polemics on formal logic in the 1930s was given in the Vol. 5 of the series Zhongguo luoji shi 中國邏輯史 (History of Logic in China), written by Zhou Yunzhi 周云之 and Zhou Wenying 周文英 (1989). Akin to the mentioned monograph, the later historical overviews of Chinese logic or logic in China tend to attach less importance to dialectical logic and mainly only provide a summary of the content of the Marxist criticism of formal logic. In specialized studies devoted to the history of dialectical logic in China more attention is usually given to the much wider discussions which developed throughout the 1950s, also referred to as the Great Debates on Logic (Luoji da taolun 邏輯大討論). By and large, the 1930s discourse on dialectical logic has been more intensively discussed in studies devoted to history of dialectical materialism in China. In more recent years these also represented the aspect of Chinese scholarship which has been most extensively translated into English, which is also the reason why the present article, in its attempt to contribute to the Western scholarship on the topic, seeks to complement Tian Chenshan's historical overview of (materialist) dialectics in China. 


\section{Setting the Stage: Translations and Early Chinese Treatises on Dialectical Logic}

An early important translation, which probably catalysed the early part of the debates on dialectical logic, was Zheng Chaolin's 鄭超麟 (1901-1998) translation of an excerpt from Georgi V. Plekhanov's (1856-1918) Fundamental Problems of Marxism (1908). The text "Dialectics and Logic (Bianzhengfa yu luoji 辯證法與邏輯)” was first published in 1924 in the influential La Jeunesse (Xin qingnian 新青年, New Youth) journal. In this, Plekhanov posited that, in opposition to formal logic, the logic of dialectics incorporated the laws of a changing, perennially moving universe. Using the principle of change as the main condition of objectiveness, Plekhanov distinguished between a "dynamic” logic (dongde luoji 動的邏輯) and a “static” logic (jingde luoji 靜的邏輯). Because, according to classic dialectics of nature, movement arises as a result of inner contradictions that underpin all existence, a "dynamic" logic would have to integrate the principle of contradiction into its fundamental laws. Thus, if the partial and subjective formal logic asserts that "yes is yes, and no is no", the "dynamic" dialectical logic reflects the principles of movement by postulating that "yes is no, and no is yes". By that token dialectical logic surpasses formal logic in realism and objectiveness. He believed that, while formal logic is concerned mainly with a mechanical idea of motion, dialectical logic takes into account the inner characteristics of change as such, and while formal logic is only concerned with the rational formal characteristics of human thought, dialectical logic encompasses the laws which underpin all aspects of material existence (Plekhanov 1924).

In the following years, the increase in the number of Chinese translations of classical and contemporary Marxist works broadened the scope of available material on the topic in China. Through the gradual introduction of work and thought of Hegel, Marxist intellectuals also became familiar with certain aspects related to the Hegelian roots of Marxist dialectics as well as the notion of dialectical logic itself. At the same time, translations of Engels's thought on the dialectics of nature and some minor aspects of Lenin's view on dialectical materialism helped Chinese intellectuals to gradually gain a more comprehensive view of the foundations of, as it were, the "classical" philosophy of dialectical materialism.

A significant increase in both translations and Chinese treatises on dialectical or dynamic logic occurred around the year 1929, in the framework of the 
general surge in Chinese translation of quintessential works of Marxism. ${ }^{4}$ The early translations of works on dialectical logic included Ke Bonian's 柯伯年 (1904-1985) translation of Josef Dietzgen's (1828-1888) Dialectical Logic (Bianzhengfa de luoji 讋證法的邏輯) from 1930, and Peng Weisen's 彭葦森 (?) translation of A. K. Toporkov's Elementary Principles of Dialectical Logic (Bianzheng luoji zhi jiben yuanli 辯證邏輯之基本原理) from 1932, among others. The earlier presence or even overall relevance of the notion of "dynamic logic” (dongde luoji 動的邏輯) in Chinese intellectual discourse was also affirmed by the pragmatist logician and psychologist Shen Youqian's 沈有乾 (Eugene Shen, 1899-?) review of B. Bogoslovsky's book The Technique of Controversy: Principles of Dynamic Logic (1928), where the so-called "dynamic logic" was treated as the third contemporary alternative to the "orthodox Aristotelian logic" (Shen 1930,1). The remaining two contending logics were the form-centred mathematical logic and the profoundly psychologistic pragmatist logic (or "experimental logic") (ibid.).

Another notion synonymous to dialectical logic, the "logic of contradictions" (maodun luoji 矛盾邏輯) was discussed in an early example of a Chinese treatise on dialectical materialism, Guo Zhanbo's 郭湛波 (original name Guo Haiqing 郭海清, 1905-1989) A Study of Dialectics (Biazhengfa yanjiu 讋證 法研究) from 1930. In this book, Guo discussed the dialectical method as a form of logic equal in value to Western formal logic. One year later, Guo published "A Comparative Study of Formal Logic and Dialectics (Xingshi luoji yu bianzhengfa de bijiao yanjiu 形式邏輯與辯證法的比較研究)”, where he already expounded on "logic of contradictions" as a logic completely dissimilar to formal logic. Following the paradigm of Plekhanov, he described the latter as a narrow, static and extremely abstract perspective on reality, while in dialectical logic he recognized such characteristics as dynamism, wholeness and a practical approach. According to Guo, its main principle was to penetrate the inner contradiction between "movement in stillness and stillness in movement" and the "identity in differences and differences in identity". At the time, Guo found the resolution of the relation between dialectical and

4 Such as Li Tiesheng's 李鐵聲 translation of Bukharin's Dialectical Materialism, Yang Dongchun's 楊東 translation of Josef Dietzgen's Materialist View of Dialectics, and Lin Boxiu's 林伯修 translation of Deborin's Materialist Dialectics and Natural Sciences were all published in 1929. Ling Yingfu's 凌應甫 translation of Deborin's Introduction to Materialist Dialectics was published in 1930, and Du Weizhi's 杜畏之 translation of Engels' Dialectics of Nature in 1932. The year 1935 saw the publication of Li Da's and Lei Zhongjian's 雷仲堅 translation of Shirokov's Textbook of Dialectical Materialism (Bianzhengfa weiwulun jiaocheng 讋證法唯物論教程) and Pan Gushen's translation of the Soviet manual Outline of Dialectics of Natural Sciences (Bianzhengfa de ziran kexue gailun 讋 證法的自然科學概論). 
formal logic in their complementarity, rather than in precedence of one over the other. ${ }^{5}$

Between 1930 and 1932, individual treatises on Hegel's dialectic and related questions started to emerge. In 1930, for instance, Shen Zhiyuan 沈志遠 (1902-1965) composed his book Hegel and Dialectics (Heigeer yu bianzhengfa 黑 格爾與辯證法), which touched on what Shen called Hegel's "logic of revolution” (geming de luoji 革命的邏輯) and his idea of sublation (Ger. Aufhebung), as philosophers and other scholars such as He Lin 賀麟 (1902-1992) and Zhou Gucheng 周穀成 (1898-1996) started pondering Hegel's notion of dialectics more intensively from various standpoints. The early signs of Chinese Marxists' discovery of Hegelian dialectics came to expression, for example, in Wang Zhaogong's 王昭公 (?) controversial article “The Decline of Formal Logic and Completion of a New Scientific Methodology (Xingshi luoji zhi bengkui yu xin kexue de fangfalun zhi wancheng 形式邏輯之崩潰與新科學的方法論之 完成)” from 1931. In his paper, Wang enunciated that Hegelian dialectics had already superseded formal logic and negated its fundamental laws. Hegel's dialectics, however, represented only the first stage in the subsequent development of materialist "synthetic" (zonghe 綜合) scientific methodology. ${ }^{6}$

Between 1932 and 1934, perhaps the most important platform through which ideas of both dialectical materialism as well as logical positivism and mathematical logic were disseminated was the "World Currents of Thought (Shijie sichao 世界思潮)” column in the Dagong bao 大公報 (L'Impartial) newspaper (Tianjin). The chief editor of the column was Zhang Shenfu 張申府, original name Songnian 崧年 (1893-1986), who was a professor of mathematical logic and modern Western philosophy (specializing in Russell and the Vienna School) at Qinghua University, as well as an ardent propagator of dialectical materialism and one of the original founders of the Communist Party of China. In the early 1930s, Zhang developed a syncretistic philosophical worldview, whose main goal was a synthesis between dialectical materialism and logical analysis. During his editorship of the "World Currents of Thought" column, Zhang himself published a wide array of articles and translations on contemporary logic, while the topics

5 In 1932, the philosopher Zhu Baiying 祝百英 (original name Zhu Tingzhang 竺廷璋, alias Fang Yiru 方亦如?)—writing under the pseudonym Yiying 亦英, composed two essays, “Formal Logic and Contradictory Logic in Epistemology (Renshilun zhong de xingshi lunli yu maodun lunli 認識論中的形式論理與矛盾論理)" and “Rule of Equilibrium and Law of Contradiction (Junhenglü yu maodunlü 均衡率與矛盾律)” in the influential Eastern Miscellany (Dongfang $z a z h i$ 東方雜志).

6 A similar approach was adopted by Li Shicen 李石岑 (1892-1934) in his article "Bianzhengfa yu xingshi luoji 讋證法與形式邏輯 (Dialectical Method and Formal Logic)” from 1932. 
in dialectical materialism and logical positivism were taken over by his younger brother, the philosopher Zhang Dainian 張岱年 (1909-2004), who later also became a lecturer at Qinghua University. Emulating his older brother, between 1933 and 1934 Dainian wrote prolifically on the possibilities of attaining a "creative synthesis" between new (dialectical) materialism, logical positivism (including logical analysis and mathematical logic) and the idealism inherent in traditional Chinese philosophy. In the 1930s, the Zhang brothers, especially Zhang Shenfu, became widely known as the proponents of a syncretistic faction of dialectical materialists, advocating the synthesis between mathematical logic and dialectical method (see Guo 1935, 183-90 etc.).

\section{Zhang Dongsun, Ye Qing and the Polemic on "Dynamic Logic”, 1933-1936}

Although the main debate on dialectical materialism between Zhang Dongsun and his followers on one side, and Ye Qing and other Marxists on the other, had already started in 1931, the discussion began to involve dialectical logic only around 1933 (cf. Tian 2005, 110). Apart from the influential Dagong bao, where Zhang Dongsun's article which sparked the debate had first appeared, ${ }^{7}$ another important locus of the discussion was also the New China (Xin Zhongua 新中華) review. Following the initial confrontations between Marxists and the critics of dialectical materialism, led by Zhang Dongsun, another one of Zhang's articles, “Is Dynamic Logic Possible? (Dongde luoji shi keneng de ma? 動的邏輯是可能 的嗎?)”, published in the abovementioned periodical, opened a new minor discussion on dialectical and formal logic.

In his essay from 1933, Zhang refuted the plausibility of the concept of "dynamic logic", pointing out that within logic there is no such polar antagonism as that between a static and dynamic quality (Rošker 2015,112). By a related token, Zhang stressed that dialectical logic can only be considered a form of methodology, which meant that it pertained strictly to dialectical principles as inherent in cognitive models and hence could not be a priori objective. He further criticized both prevailing interpretations of the relationship between formal and dialectical logic in Marxist discourse, namely that dialectical logic can either supplement or completely replace formal logic, stating that while the

7 The polemics were probably initiated by Zhang Dongsun's article "I also Discuss Dialectical Materialism (Wo yi tantan bianzheng de weiwulun 我亦談談辯證的唯物論)", which appeared in the “Modern Currents of Thought (Xiandai sichao 現代思潮)” column of the Dagong bao newspaper in September 1931. 
dynamic aspect is already encapsulated in natural science per se, in epistemology there only exists a dualism between intuition and intellect, where formal logic represents the only function (yong 用) of the latter. ${ }^{8}$ Furthermore, since reality is always in a "dynamic" state, this entailed that there cannot be something called a "static" mode of understanding, which in turn implied that the notion of "dynamic logic" had no meaning.

Not long afterwards, Ye Qing's "A Dynamic Logic is Possible! An Answer to Professor Zhang Dongsun (Dongde luoji shi keneng de! Da Zhang Dongsun jiaoshou 動的邏輯是可能的! 答張東蓀教授)” and Deng Yunte's 鄧雲特 (?) essay "Formal Logic or Materialist Dialectics? (Xingshi luoji haishi weiwu bianzhengfa? 形式邏輯還是唯物辯證法?)” were published in the new “Polemic on 'Dynamic Logic' ("Dongde luoji” lunzhan 動的邏輯論戰)” column of the New China review. Both emphasized that in his criticism of dialectical logic Zhang misunderstood Hegel's idea of sublation and the dialectical principle of evolution in the context of the relationship between formal and dialectical logic. Ye further claimed that dialectical logic was the "affirmation of negation" of formal logic, and thereby a higher evolutionary stage of the latter. Moreover, Ye asserted that in its evolution dialectical logic had already integrated the inductive method through a positive development process and was therefore equal to a "general scientific method" (pubian de kexue fangfa 普遍的科學方法), whereas by means of sublation (Aufhebung) it absorbed the method of deduction. A major corollary to that was that dialectical logic was more comprehensive than any other form of logic, and it also implied that it was more objective than formal logic, as well as more universal.

The Zhang-Ye debate on dialectical materialism reached its peak by 1934, while in 1934 and 1935, respectively, Zhang and Ye, each according to his own views, compiled an anthology of the most important contributions to the debate (see Zhang 1934a; Ye 1935a). In 1934, Ye Qing published his lengthy work $A$ Critique of Zhang Dongsun's Philosophy (Zhang Dongsun zhexue pipan 張東荪哲學批判) in two volumes. The problem of "dynamic logic" was addressed at length in the second volume of Ye's book (see Ye 1934, 615-60). In 1934, Zhang recapitulated his criticism in various writings, such as "A Few Fashionable Questions in the Forum of Ideas (Sixiang de luntan shang jige shimao wenti 思想的論壇上幾個時髦問 題)”. In this lengthy essay, Zhang gave an overview of the main questions raised in the framework of the ongoing discussions, such as "Can dialectics replace the law of identity?", “Is contrariety (xiangfan 相反) contradiction (maodun 矛盾)?”, “Are

8 Zhang claimed that he followed Russell's logicist idea of logic. 
all changes sublation (xiaoliu 消留, Aufhebung)?”' and so on. This time Zhang's criticism of the idea of dialectical logic was also directed exclusively against Plekhanov's theory of logic. ${ }^{10}$

On both sides a number of other discussants addressed the question of dialectical logic. On Zhang Dongsun's side of the debate, the most notable argument against dialectical logic came from Mou Zongsan 牟宗三 (1909-1995), who at the time maintained a deep interest in mathematical logic.

Mou Zongsan raised his objections against the Marxist notion of dialectical logic in an article entitled "Logic and Dialectical Logic (Luoji yu bianzheng luoji 邏 輯與辯證邏輯)” from 1934. In his argument against dialectical logic, Mou draw from the idea of pure logic advanced in the contemporary Chinese New Realist circles. Having repeated the same maxim as advanced by the Qinghua logician Jin Yuelin in the very same year (see Jin 1934), Mou stated that there only exists one logic, which is objective, absolute, universal, normative and in accord with "what is potentially so". Mou presented a rare perspective in the debate, in which the mathematical logic of Principia Mathematica was described as the highest developmental stage of formal logic. In the same text, Mou implicitly indicated that "modern" formal logic was far beyond the antiquated Marxist doctrine on logic. After having outlined the general characteristics of "pure logic", Mou compared his fundamental laws (principles) with those of the proposed dialectical logic. He noted that the main flaw of dialectical logic resided in its definition of the "law of contradiction", which did not discern between the identity expressed by a proposition and negation in the form of a term (mingcheng 名稱). In other words: dialectical logic distorted the law of contradiction by treating “is A" (是 A) as the opposite value of "non-A" (非 A). This all originated in its misunderstanding of the law of identity, which could be defined using three different concepts of identity (cf. Suter 2017, 158-67).

From his own point of view, identity and contradiction were based on the a priori essence of human intellect, which meant that they can neither be proved nor disproved, nor can they be derived from each other. Furthermore, these laws are

9 Zhang used the word xiaoliu 消留as a translation of Hegel's Aufhebung or the verb aufheben. The term combined the words xiaosbi 消失 “dissolution” and baoliu 保留 “preservation”. More commonly used Chinese terms for sublation, such as qiyang 棄楊 and zhiyang 止楊, had been borrowed from Japanese sources.

10 By 1939, Zhang seems to have changed his mind. In his novel theory of cultural conditionality of logic (see Zhang 1939), Zhang treated dialectical logic as one of the four kinds of logic, calling it "the socio-political" logic. He even claimed that although Chinese culture did not produce mathematical logic because there was no historical need for it, metaphysical and socio-political logic had always constituted an important segment of traditional Chinese thought. 
applicable solely to logical propositions and bear not direct relation to the factual state of affairs, or even time and space. This was in essence his idea of pure logic. To further illustrate how dialectical logic can lead to inconceivable fallacies, Mou cited a few examples from Jin Yuelin's article "Immediate Inference of A, E, I and O” (1930). Following his direct criticism of Chen Baoyin's 陳豹隱 (original name Chen Qixiu 陳啓修, 1886-1960) lectures on dialectical materialism from $1932,{ }^{11}$ Mou then concluded that dialectical logic is not logic, but a theory occupied with analysing facts; neither is it a methodology nor can it be considered a special method of thinking. Finally, he also listed four Marxist misconceptions about logic: (i) that formal logic is the starting point for analysis of the world; (ii) that dialectical logic is a scientific fact; (iii) that objective facts are logic and that dialectical logic is the counterpart of formal logic; and (iv) that the laws of logic depict objective facts. ${ }^{12}$

\section{Internal Marxist Debates: From the Relationship between Dialectical and Formal Logic to Sublation of Formal Logic, 1935-1939}

The early confrontations between the group of philosophers led by Zhang Dongsun and Ye Qing and other Marxists led to two particular developments: on the one hand, they gave rise to inner philosophical debates in the circles of Chinese adherents of dialectical materialism, in which more moderate interpretations of the classical doctrine, such as that of Ye Qing, were set in contrast with the narrower, mainstream expositions of current Soviet doctrine. On the other hand, the early debates communicated a sense of the broader intellectual relevance of dialectical logic - as a most advanced method reasoning with practical applications in all everyday matters and not only in strict formal inference- to the members

11 “Methodology of Studies in Social Sciences". Chen's lectures were recorded by Xu Wanjun 徐萬鈞 and Lei Jishang 雷季向 and published as a monography in 1932.

12 Earlier in 1932, a similar attempt had been made by Wang Dianji 汪奠基 (1900-1979) in his article "A Critique of Principles of Formal Logic (Xingshi luoji yuanli de pipan 形式邏輯原 理的批判)". Wang had shown how formal logic had been superseded and rectified by mathematical logic, a form of logic closely connected to contemporary science and mathematics. By having demonstrated how traditional formal logic could not be considered representative of deductive logic as such, Wang rendered the Marxist criticisms outdated and irrelevant for the contemporary discourse on logic. Secondly, if the exponents of dialectical logic claimed that dialectical logic was superior or equal in value to formal logic, the same could not hold for mathematical logic. Finally, this also implied that Marxist evaluation of deductive logic ought to take place within the comparison between dialectical and contemporary mathematical logic, were the laws of contradiction and excluded middle had already been proven inadequate. 
of Marxist circles, stimulating their active engagement in the developing public discourse. Thus, in 1935, an intensive debate developed between Ye Qing and Ai Siqi, which reflected the Chinese instigation of the Soviet controversy between Deborin's and the official interpretation of dialectical materialism (Tian 2005, 112). Concurrently, in $1935, \mathrm{Li} \mathrm{Da}$ also started a new chapter in the debate on the relationship between dialectical and formal logic, which channelled and proliferated the more recent mainstream Soviet doctrine into Chinese Marxist discourse on logic. The year 1935 thus marked a pivotal moment in the history of Marxist discourse on logic in China, mainly because it delineated the main direction of Chinese debate on the same topic for the following few decades.

\section{Ye Qing and Ai Siqi, 1936}

In his Lectures on Philosophy (Zhexue jianghua 哲學講話), first published in 1936, Ai Siqi set out to refute the notion of identity in formal logic. In a derogatory manner, Ai remarked that, in accordance with its paradoxical law of identity, formal logic leads one to believe that the young are always the young, even after they become adults. Otherwise, Ai's criticism of logic further accentuated the main points of contention against formal logic as outlined by Li. (Ai 1936a, 151-63) ${ }^{13}$ In the same year, Ai's critique was countered by Ye Qing, who published two articles titled "Formal Logic and Dialectical Logic (Xingshi luoji yu bianzheng luoji 形式邏輯與辯證邏輯)”. As in his early reflections, Ye assumed a more moderate position, claiming that dialectical logic was, in fact, a synthesis between inductive and deductive logic. Ye advocated a resolution to the problem of the relationship between formal and dialectical logic dissimilar from the idea of dialectical sublation, in which the fundamental laws of both logics would have been conjoined in a harmonic unity. Ye's ideal of complementarity (xiangfan xiangcheng 相反相 成) presupposed that in the new logic the laws of dialectics would be juxtaposed against the principles of formal logic, forming a series of principles that would correspond to the law of unity of contradictions (maodun tongyi lü 矛盾統一律). If in formal logic the law of identity stipulated that " $\mathrm{A}$ is $\mathrm{A}$ ", in dialectical logic its principle of identity would have been directly modified to state that "at the same time A is A and A is not A" (Ye 1936a,73). In turn, Ye also impugned Ai's critical remarks on laws of contradiction and identity in formal logic, saying:

The statement "this young person is a salesman" is clearly (an example) of the use of the law of excluded middle from formal logic. The formula

13 In the same year Ai also wrote a few responses to other participants in the debate. (See, for instance Ai 1936b) 
of the law of excluded middle is “ $\mathrm{A}$ is $\mathrm{B}$ or $\mathrm{A}$ is non- $\mathrm{B}$ ” ( $\mathrm{A}$ 是 $\mathrm{B}$ 或是非 $\mathrm{B}$ ), and the meaning of "this young person is a salesman" is the same as "A is $\mathrm{B}$ ". The formula of the law of unity of contradictions would here be "A is $B$ and $A$ is non- $B$ ” ( $A$ 是 $B$ 又是非 $B)$, that is “yes-no, no-yes”. Following that example, we get: "this young person is a salesman and a non-salesman" or "this young person is a salesman and also is not a salesman". (ibid., 80)

Ye stated that Ai did not properly understand the laws of contradiction and excluded middle in formal logic, and hence was unable to understand the real relation between formal and dialectical logic. By advocating his harmonistic view, Ye caused a considerable rift between two interpretational currents among Chinese adherents of dialectical materialism. He caused a stir among the hard-line Marxists who maintained that dialectical logic was superior to formal logic, whose responses subsequently caused the debate to shift to a different level. Thus, in 1937 a debate on the “sublation of formal logic" (xingshi luoji de yangqi 形式邏輯的揚棄) started to ferment among Chinese Marxists, which ultimately reached its peak in 1939.

\section{Li Da on Logic, 1935-1936}

In the years 1935 and 1936, Li Da's writing aimed at rectifying the content of the Chinese discourse on dialectical logic. In comparison with more, so to say, "moderate" interpretations of the dialectical variety of logic, his article "Dialectical Logic and Formal Logic (Bianzheng luoji yu xingshi luoji 讋證邏輯與形式邏 輯)" utilized a more politically coloured rhetoric, which depicted formal logic as a mere ideological invention of metaphysicians and idealists.

All metaphysicians or idealists are not aware that in their mental view, apart from formal logic, there is also a dialectical logic. They praise formal logic as the science of the method of correct thinking and declare that formal logic is a scholarly instrument "unchangeable in all times, countries and people" and that for any learning, problem and course of events formal logic is (always) the right method of thinking. Whenever a polemic arises about a certain question, they will employ this "Mr. Formal Logic" to serve as their advocate. Therefore, metaphysical and idealist views on nature, on society as well as their general worldview all take formal logic as their (only) methodology. (Li 1935a, 1)

Akin to other examples of Soviet criticism, Li's text revolved around the three laws of logic. Li's updated exposition of the Soviet dogma led him to reject all 
three laws as abstractions of the principle of identity, claiming that a false notion of identity had caused formal logic to neglect the true principle of dialectical unity of identity and difference. Hence, according to Li, formal logic was devoid of any real substance. It was:

- Subjectivism, whose form did not represent objective reality.

- Devoid of an evolutionary or developmental perspective.

- It ignored the principle of interrelatedness of all phenomena (dialectical logic was "comprehensive" or "holistic").

- Its principles were isolated from all aspects of social practice. (ibid., 4-5)

$\mathrm{Li}$ also presented a theory of development of logic, which was based on the theory of "historical developmental process of human cognition" from Engels's Dialectics of Nature. In Li's historical model, formal logic emerged at the developmental stage of "metaphysical thought", while its successor, mathematical or symbolic logic, developed under "the social conditions of the age of (capitalist) manufactures". Because it emerged in the same period as natural sciences and modern mathematics, it absorbed their knowledge and emulated their form. In contrast, dialectical logic developed at the highest evolutionary stage of human thought. Consequently, dialectical logic was not only a form of logic which superseded mathematical logic, but a higher form of thought which sublated all the lower forms: it cleansed the idealist elements and integrated its concrete elements. In this regard, Li's idea of the superiority of dialectical logic was closer to Hegel's idea of sublation (Aufhebung) (see Hegel 1986, 365-67, 565). On the other hand, sublation also implied a conceptual dissolution of formal logic as such.

Other contemporary writings of Li reveal his strong interest in a dialectics of nature, and especially in a Marxist philosophy of mathematics. He maintained a positive view of mathematics and called it a universal language for describing the spatial principles of material reality (see Li 1935b; 1936a). In 1936, however, Li also published a number of other articles on logic. In an article entitled "Dynamic Logic" he reviewed Plekhanov's idea of dialectics as the logic of change. In a lecture entitled “The Logic of Dialectics (Bianzhengfa de luoji 讋證法的邏輯)”, which was recorded by Yang Mingzhang 楊明章 and published in Yanching University Weekly Magazine (Yanda zhoukan 燕大周刊), Li integrated the notion of "dynamic logic" into his general outline of characteristics of the advanced form of dialectical logic. In "Dynamic Logic" Li further defined change as the embodiment of two main principles: the world as a totality of the material transformations and general developmental laws of the physical world. He treated dialectical materialism as scientific truth and philosophy as scientific methodology, and 
disputed Bohr's model of atom as an argument against the claims of dialectical materialism, defining the objectivity of science or philosophy in terms of their accordance with the process of change and practice. In the same year Li Da's "Fundamental Principles of Logic (Luoji de genben yuanli 邏輯的根本原理)” and “Essentials of Logic (Luoji dayi 邏輯大意)” were published in the Zhongshan Institute for Culture and Education Quarterly (Zhongshan wenhua jiaoyu jikan 中山 文化教育季刊).

\section{Sublation of Formal Logic, 1937-1939}

By 1937, Ye recapitulated his views in yet another article on "Formal Logic and Dialectical Logic (Xingshi luoji yu bianzheng luoji 形式邏輯與辯證邏輯)”, which presented a comprehensive response to all criticisms directed against him. Later the same year, Ai Siqi epitomized and further expanded the criticisms against Ye in an extensive monograph Critique of Ye Qing's Philosophy (Ye Qing zhexue pipan 葉青哲學批判). Finally, in the same year Ye presented an expanded exposition of his views on logic in his monograph Problems of Logic (Lunlixue wenti 論理學問 題), which also devoted part of its discussion to mathematical logic-Ye's sources were Kurt Joachim Grau's Grundriß der Logik (1921) (translated into Chinese in 1927 by Chen Daqi 陳大齊) and Wang Dianji's A Treatise on Logic and Mathematical Logic (Luoji yu shuxue luoji lun 邏輯與數學邏輯論) from 1927. Although Ye believed that, as the most developed Western logic, mathematical logic possessed the same theoretical limitations as its predecessor, he nevertheless made the following striking conclusion:

I have already quoted Engels's words, which say that dialectics is "a theory of thought and its laws" or "the science of the laws of the process of cognition in itself". In that way, dialectics must also be an investigation of the form(s) of thought. That is so because, besides content, thought has also got form. Content is a reflection of external things, and [the discipline] which investigates it is epistemology. Then, the only thing which reflects one's [inner] self is form. And this form (xingshi 形式) is thought, that is the form of movement (yundong xingtai 運動形態) of external things taken in (shequ 攝取 “absorb", "receive") by our thinking organ (siguan 思官). Because of that dialectics must be the science of the form of thought. According to my view, following the example of formal logic, dialectics could also adopt the mathematical form (shuxue xingtai 數學 形態) and become a dialectical mathematical logic (bianzhengfa de shuli luoji 讋證法的數理邏輯). (Ye 1937b, 138) 
Between 1937 and 1938, a series of treatises recapitulating the views expressed in the previous years, supported with new material on the matter, were published. These treatises argued in favour of either of the two options. Thus, for instance, in 1937 Pan Zinian 潘梓年 (1893-1972) composed a treatise entitled Logic and the Science of Logic (Luoji yu luojixue 邏輯與邏輯學). Pan presented an overview of the materialist version of the history of logic, propagating the idea that formal logic had been sublated by the dialectical logic. The book was probably the first Chinese monograph to offer a comprehensive overview of the Soviet Marxist theory of physical matter. One year later (1938), the book was republished under the title Science of Logic and Logical Methods (How Dialectics Sublated Formal Logic) (Luojixue yu luojishu (Bianzheng zenyang yangqi le xingshi luoji) 邏輯學與邏輯 術(辯證法怎樣揚棄了形式邏輯)), to emphasize its main doctrinal purport and orientation.

The number of articles advocating the sublation of formal logic increased between 1937 and 1939. Probably the earliest article adamantly asserting the orthodox Marxist view on formal logic was Feng Ding's 馮定 (1902-1983) “Sublation of Formal Logic (Xingshi luoji de yangqi 形式邏輯的揚棄)” from 1937. Feng, who at the time was writing under the pseudonym Beiye 貝葉, outlined the main paradigm which was to underlie the forthcoming mainstream discourse on the sublation of formal logic in Chinese Marxist circles. Feng claimed that, due to its idealist essence, formal logic lacked all practical implications in the modern world: "Formal logic could indeed be used in everyday domestic environment, but this kind of domestic environment would be an old-fashioned one, with no deeper connection to the (current) society ..." (Feng 1937, 252). Feng continued: "In the future, dialectics will enable small children to effortlessly acquire advanced knowledge." (ibid.) Whereas, in the same future, dominated by dialectical materialism, the antiquated formal logic would be only found "in the local museum".

By 1939, the idea of sublation became commonly accepted in Chinese Marxist circles. The only question which still remained to be answered was: how was it supposed to be carried out? Or, in other words: to what degree ought formal logic be assimilated ${ }^{14}$ into dialectical logic? A notable case against the total elimination of formal logic was put forward by Ai Siqi in his critique of Pan Zinian's book from 1938 (Ai 1939). This time, Ai spoke about a "critical assimilation of formal logic". Although he described modern formal logic as a complete antithesis to dialectical logic - since its main purpose was to resolve the paradoxes or contradictions from human thought-he still believed that it contained numerous useful

14 It appears that for some authors, like Ai Siqi, sublation was synonymous or at least closely related to "assimilation". This again shows a substantial diversity of interpretations of these key notions in Chinese Marxist circles at the time. 
"techniques" which could be extracted from their idealist background and inculcated into dialectical logic. In the same manner, Ai proposed that the laws of formal logic could be reformulated to fit dialectics and fused into an expanded body of dialectical logic, where deduction and induction would attain a complementary union. In comparison with the standpoint advocated in his earlier writings, the ideas presented in his work from 1939 appear to have conveyed a less narrow notion of logic.

The debate was more or less concluded by Li Da's article "On the Question of Sublation of Formal Logic (Xingshi luoji yangqi wenti 形式邏輯揚棄問題)” (1939), which also recapitulated the most important points indicated in the preceding discussions. At the same time, Li also presented some new arguments. As the chief contemporary sources in the theory of logic Li listed Wang Tefu's 王 特夫 The System of Logic (Lunlixue tixi 論理學體系) (1933), Lin Zhongda's 林仲 達 vitalist treatise Synthetic Logic (Zonghe Luoji 綜合邏輯), Ai Siqi’s Methodology of Thought and Pan Zinian's Science of Logic and Logical Methods. In addition to the abovementioned commonly advocated views on the history of dialectical and formal logic, $\mathrm{Li}$ also provided a detailed criticism of two contending contemporary forms of logic: Russell's mathematical logic and Dewey's experimentalist logic. Li criticized the former, saying that:

The philosophical foundation of mathematical or symbolic logic is rationalism (lixinglun 理性論). Rationalism advocates that the actual world must be explained in terms of the truth as contained in human intellect. In consequence, mathematical or symbolic logic advocates that logic is merely a formal development of human intellect as such, it is a boundless derivation and advancement of reason. This is why mathematical logic constructs logic on the forms of thinking and tries to assemble these forms so that they might be mystically turned into an illusion of the objective world. Since this school of logic investigates only the developmental forms of reason, it must necessarily resort to the use of the deductive method. However, no other discipline is more able to rigorously use the method of deduction than mathematics. Therefore, it was necessary that this logic, which focuses on form as its object of research, adopts mathematical method of deduction, ... claims that akin to mathematics logic has also got permanent and unchanging formulae, and advocates that the forms of thinking contain some unchanging "logical constants", and that (in this manner) one can detect objective facts. Therefore, the members of this school of logic, such as Mou Zongsan, advocate that "logic is universal, formal and semantically undefined inferential relation 
between (different) propositional functions" ... We could really call this school of logic an extreme and pure (version) of formal logic. (Li 1939, 111-12)

Finally, in $1939 \mathrm{Li}$ also enumerated four major laws of formal logic, including the law of sufficient reason (chongzu liyou lü 充足理由律). Correspondingly, he also listed four kinds of limitations of formal logic: (1) formal logic is divorced from epistemology, (2) it totally neglects the developmental viewpoint, (3) it totally neglects the aspect of interconnectedness of things, and (4) it separates theory and practice. As noted above, Li's critique of mathematical logic followed the very same lines, with a special emphasis on the assertion that its sole focus was the form of human reasoning.

\section{Conclusion}

Though presenting only a superficial view of the debates on dialectical and formal logic of the 1930s, the above discussion confirms the conjecture made in the introduction to this article, namely that the complex network of influences, contributions and opinions was webbed into the general intellectual discourse on dialectical materialism and logic before and during the 1930s debates in China. A brief comparison of arguments and advocacies presented on both sides of the debates shows that at the time the discourse was undergoing constant change, while at the same time some doctrinal precepts, such as the extensions and derivations of the paradigm set down by Plekhanov or the Marxist interpretation of the basic laws of logic, were consistently preserved throughout the whole period under observation. While it is highly probable that the special circumstances which arose during a time of war drastically affected or even overturned the overall intellectual trends that had ensued from the intellectual developments in the 1920s, the ideological dissonances of the late 1930s opened up a new window of opportunity for establishment of the Soviet hard-line doctrinal model in Chinese Marxist philosophical discourse.

To put it in concrete, plain terms: The main conceptual background for the abovementioned debates in the early 1930s were the general philosophical discourse on logic and science from the 1920s, on one side, and the more specialized Chinese Marxist discourse on dialectical materialism from the same period, on the other. Although the debates between Zhang Dongsun and Ye Qing ensued in direct consequence of the large-scale popularization of dialectical materialism and the sudden surge in number of publications on the topic in the late 1920s, contextually these discussions were still rooted in the discourse of the mid-1920s. Ye Qing's 
attention to Plekhanov's "dynamic logic" as the, as it were, "logic of change", and his synthetic solution of the problem of the relationship between formal and dialectical logic was thus profoundly reflective of his semi-traditional notion of dialectics, which still did not completely absorb the incoming current of sources on dialectical materialism. Similarly, the very idea of the significance of logic also derived from the developing Chinese philosophical discourse on logic from the 1920s, as well as the current developments in the notion of logic as an academic discipline at most prestigious Chinese universities in Beijing-especially the Qinghua circle of logicians and New Realists. This was also the reason why mathematical logic and the analytical notion of pure logic were brought up by the opponents of dialectical materialism so early on in the debate-Wang Dianji in 1932 and Mou Zongsan in 1933. The subsequent integration of mathematical logic in Marxist discourse on the sublation of formal logic was also a relatively special feature of Chinese debates on dialectical materialism. Historically, this tendency might have been an extension of the strong presence of Russell's philosophy of mathematics and the notion of mathematical logic in discourse generated in the early Communist circles in Beijing in the late 1910s and all of the 1920s. As mentioned above, the person facilitating a theoretical synthesis of the two theories was Zhang Shenfu, one of the cofounders of the Communist Party of China and a professor at Peking and Qinghua universities. ${ }^{15}$ Moreover, a strong syncretistic tendency has been an underlining feature of the thought of a great number of important shapers of Chinese intellectual discourse in the 1910s and 1920s, and seems to have also been retained as an important attitude in some of their students, who later became affiliated with the Chinese Marxist discourse.

On the other hand, the influx of new knowledge about the Soviet doctrine on dialectical materialism as well as other translations of classical works of Marxism caused an internal rift in the lines of Chinese Marxists. The internal antagonisms were at their peak between the years 1935 and 1937, when, for example, Ye Qing's moderate views clashed with Ai Siqi's more critical attitude towards the sublation of formal logic. Setting aside the internal tensions related to other aspects of political or philosophical doctrine, which probably existed in the Marxist circles throughout the 1930s-also due to diverging opinions with regard to the notion of "Sinicization" of dialectical materialism and science-in the years between 1937 and 1939 the views of some of those named above seem to have undergone a considerable transformation, in which parts of the discourse seem to have aligned with the sentiment of cultural relativism, which

15 Zhang's teaching on mathematical logic and dialectical materialism influenced the discussants on both sides of the debate, from Guo Zhanbo to Mou Zongsan. 
permeated the intellectual climate, allowing a greater degree of compromise between the two logics. Concurrently, different opinions finally started to converge, creating an impression of consensus and a general move towards codification of the tenets of "Chinese Marxism". ${ }^{16}$ Thus, in the end, on both sides more complementary solutions and syncretistic visions of coexistence of the "two logics" took ground. On the other hand, in the case of Zhang Dongsun the same rationale as incapsulated in the idea of "Sinicization" came to expression in the form of neo-traditional cultural relativism, and in leftist circles the harmonic synthesis as advocated by Zhang Shenfu and Zhang Dainian gradually manifested in a short-lived increase in the relevance of a more moderate notion of sublation of formal or mathematical logic into dialectical logic.

\section{Bibliography}

Ai, Siqi 艾思奇. 1936a. Zhexue jianghua 哲學講話 (Lectures in Philosophy). S.1.: Dushu shenghuo she.

—. 1936b. "Guanyu 'Xingshi luoji yu bianzheng luoji': Da Zhang Youren Qu Minggao jun deng 關於 “形式邏輯與辯證邏輯”:答張友仁䨉鳴㚖君等 (About 'Formal Logic and Dialectical Logic': An Answer to Mr. Zhang Youren, Qu Minggao and Others)." Dushu Shenghuo 4 (2): 28-33.

—. 1936c. Sixiang fangfalun 思想方法論 (Methodology of Thought). Shanghai: Shenghuo shudian.

—. 1936d. Dazhong zhexue 大衆哲學 (Popular Philosophy). Shanghai: Dushu Shenghuo chubanshe.

- (Ai Sheng 艾生). 1937a. Ye Qing zhexue pipan 葉青哲學批判 (Critique of Ye Qing's Philosophy). Shanghai: Sixiang chubanshe.

—.1937b. Zhexue yu shenghuo 哲學與生活 (Philosophy and Life). Shanghai: Dushu shenghuo chubanshe.

—. 1939. "Xingshi lunlixue he bianzhengfa: bing lüeping Pan Zinian xiansheng de 'Luojixue yu Luojishu' 形式論理學和辯證法: 並略評潘梓年先生的 “邏輯學與邏輯術” (Formal Logic and Dialectics: Also, a Brief Criticism of Pan Zinian's Science of Logic and Logical Methods)." Lilun yu xianshi (Chongqing) 1 (2): 122-31.

—. 1940. Zhexue yanjiu tigang 哲學研究提綱 (An Outline of Studies in Philosophy). S.1.: Chenguang shudian.

16 The apparent push towards the codification of the tents of dialectical materialism in Chinese Marxist circle might have also been facilitated by Stalin's promulgation of Marxist-Leninist dialectical materialism—also known as "Diamat", as the official ideology of the Soviet Union in 1938. 
Bukharin, Nikolai I. (Buhalin 佈哈林). 1929. Bianzhengfa de weiwulun 辯證法底 唯物論 (Dialectical Materialism). Translated by Li Tiesheng 李鐡聲. Shanghai: Jiangnan shudian.

Chen, Baoyin 陳豹隱. 1932. Shebui kexue yanjiu fangfalun 社會科學研究方法論 (Methodology of Studies in Social Sciences). Beiping: Haowang shudian.

Deborin, Abram (Debolin 德波林). 1929. Weiwu bianzhengfa yu ziran kexue 唯 物辯證法與自然科學 (Materialist Dialectics and Natural Sciences). Translated by Lin Boxiu 林伯修. Shanghai: Guanghua shuju.

- 1930. Weiwu bianzhengfa rumen 唯物辯證法入門 (Introduction to Materialist Dialectics). Translated by Ling Yingfu 凌應甫. Shanghai: Jiangnan shudian.

Deng, Yunte 鄧雲特. 1933. “Xingshi luoji haishi weiwu bianzhengfa? 形式邏輯 還是唯物讋證法? (Formal Logic or Materialist Dialectics?).” Dagong bao 1 (23): 69-75.

Dietzgen, Josef (Dicigen 狄慈根). 1929. Bianzhengfa de weiwu guan 辯證法的唯 物觀 (Materialist View of Dialectics). Translated by Yang Dongchun 楊東莼. Shanghai: Kunlun shudian.

- (Dizhigen 狄芝根). 1930. Bianzhengfa de luoji 辯證法的邏輯 (Dialectical Logic). Translated by Ke Bonian 柯伯年. Shanghai: Nanqiang shuju.

Engels, Friedrich (恩格斯). 1932. Ziran bianzhengfa 自然讋證法 (Dialectics of Nature). Translated by Du Weizhi 杜畏之. Shanghai: Shenzhou guoguangshe.

Feng, Ding 馮定 (Beiye 貝葉). “Xingshi luoji de yangqi 形式邏輯的揚棄 (Sublation of Formal Logic).” Zixiu daxue 1 (13): 250-52.

Guo, Zhanbo 郭湛波. 1930. Bianzhengfa yanjiu 辯證法研究 (A Study of Dialectics). Beiping: Jingshan shushe.

—. 1931. “Xingshi luoji yu bianzhengfa zhi bijiao yanjiu 形式邏輯與辯證法之 比較研究 (A Comparative Study of Formal Logic and Dialectics).” Beida xuesheng zhoukan 2 (1): 23-27; 2 (2): 19-24.

- 1935. Jin sanshi nian Zhongguo sixiangshi 近三十年中國思想史 (Chinese Intellectual History in the Last Thirty Years). Beiping: Dabei shuju.

Hegel, G. W. F. 1986. "Wissenschaft der Logik II.” In Georg Wilhelm Friedrich Hegel Werke, vol. 6. Frankfurt am Main: Suhrkamp.

Heubel, Fabian. 2019. "Beyond Murderous Dialectics." Asian Studies 7 (1): 37-54. https://doi.org/10.4312/as.2019.7.1.37-54.

Jin, Yuelin 金岳霖. 1930. “A, E, I, O de zhijie tuilun A, E, I, O的直接推論 (Immediate Inference of A, E, I and O)." Zhexue pinglun 3 (3): 8-64.

—. 1934. "Bu xiangrong de luoji xitong 不相融的邏輯系統 (Alternative Systems of Logic).” Qinghua xuebao 9 (2): 309-29.

Li, Da 李達. 1935a. “Bianzheng luoji yu xingshi luoji 辯證邏輯與形式邏輯 (Dialectical Logic and Formal Logic)." Faxue zhuankan 5: 1-22. 
—. 1935b. “Shuxue de benzhi he yingyong 數學的本質和應用 (The Essence and Use of Mathematics)." Kexue shijie 4 (11): 1043-44.

—.1936a. “Shuxue he ziran kexue 數學和自然科學 (Mathematics and Natural Science).” Kexue shijie 5 (8): 667-70.

—.1936b. “Dongde luoji 動的邏輯 (Dynamic Logic).” Shehui shenghuo 1 (1): 37-39.

—. 1936c. “Bianshengfa de luoji 讋證法的邏輯 (The Logic of Dialectics).” Recorded by Yang Mingzhang 楊明章. Yanda zhoukan 7 (2): 6-8; 7 (4): 17-20.

—. 1936d. "Luoji de genben yuanli 邏輯的根本原理 (Fundamental Principles of Logic)." Zhongshan wenhua jiaoyuguan jikan 3 (1): 283-307.

—.1936e. “Luoji dayi 邏輯大意 (Essentials of Logic).” Zhongshan wenhua jiaoyuguan jikan 3 (3): 975-93.

—. 1939. “Xingshi luoji yangqi wenti 形式邏輯揚棄問題 (On the Question of Sublation of Formal Logic)." Lilun yu xianshi 1 (2): 101-21.

Li, Shicen 李石岑. 1932. “Bianzhengfa yu xingshi luoji 讋證法與形式邏輯 (Dialectical Method and Formal Logic).” Dushu zazhi 2 (5): 27-46.

Lin, Zhongda 林仲達. 1936. Zonghe luoji 綜合邏輯 (Synthetic Logic). Shanghai: Zhonghua shuju.

Mou, Zongsan 牟宗三. 1934. “Luoji yu bianzheng luoji 邏輯與辯證邏輯 (Logic and Dialectical Logic).” In Weiwu bianzhengfa lunzhan 唯物讋證法論戰 (The Polemic on Materialist Dialectics), edited by Zhang Dongsun 張東䒺, vol. 1,93-138. Beiping: Minyou shuju.

Pan, Zinian 潘梓年. 1937. Luoji yu luojixue 邏輯與邏輯學 (Logic and the Science of Logic). Shanghai: Shenghuo shudian.

—. 1938. Luojixue yu luojishu (Bianzheng zenyang yangqi le xingshi luoji) 邏輯學 與邏輯術(辯證法怎樣揚棄了形式邏輯) (Science of Logic and Logical Methods (How Dialectics Sublated Formal Logic). Shanghai: Shenghuo shudian.

Plekhanov, Georgi. 1908 (1928). "Osnovnye Voprosy Marksizma (Fundamental Problems of Marxism)." In Sochinyeniya (Works) Vol. 18 - Ot Utopii k Nauke (From Utopia to Science), edited by D. Rjazanov, 340-504. Moscow, Leningrad: Gosizdat.

— (Puliehanuofu 普列哈諾夫). 1924. “Bianzhengfa yu luoji 辯證法與邏輯 (Dialectical Method and Logic).”Translated by Zheng Chaolin 鄭超麟. Xin qingnian 3: 41-49.

Rošker, Jana S. 2015. "Two Models of Structural Epistemology: Russell and Zhang Dongsun." International Communication of Chinese Culture 1 (2): 109-21. http://link.springer.com/article/10.1007/s40636-015-0020-3, doi: 10.1007/s40636-015-0020-3.

—. 2019. "Li Zehou and His Rocky Relationship with Marx." Asian Studies 7 (1): 201-15. https://doi.org/10.4312/as.2019.7.1.201-215.

Shen, Youqian 沈有乾. 1930. “Dongde luoji 動的邏輯 (Dynamic Logic).” Renwen (Shanghai) 1 (7): 1-3. 
Shen, Zhiyuan 沈志遠. 1932. Heigeer yu bianzhengfa 黑格爾與辯證法 (Hegel and Dialectics). S.1.: Bigengtang shudian.

Suter, Rafael. 2017. Logik und Apriori zwischen Wabrnebmung und Erkenntnis: Eine Studie zum Frübwerk Mou Zongsans (1909-1995). Berlin: De Gruyter.

Tian, Chenshan. 2005. Chinese Dialectics: From Yijing to Marxism. Lanham, Boulder: Lexington Books.

—. 2019. "Mao Zedong, Sinization of Marxism, and Traditional Chinese Thought Culture." Asian Studies 7 (1): 13-37.https://doi.org/10.4312/as.2019.7.1.13-37. Toporkov, Aleksey K. (Taopoerkaofu 陶潑爾考夫). 1932. Bianzheng luoji zhi jiben yuanli 讋證邏輯之基本原理 (Elementary Principles of Dialectical Logic) Translated by Peng Weisen 彭葦森. Shanghai: Chunqiu shudian.

Wang, Dianji 汪奠基. 1927. Luoji yu shuxue luoji lun 邏輯與數學邏輯論 (ATreatise on Logic and Mathematical Logic). Shanghai: Shangwu yinshuguan.

—. 1932. “Xingshi luoji yuanli de piping 形式邏輯原理的批評 (A Critique of the Principles of Formal Logic).” Biance zhoukan 1 (9): 7-10.

Wang, Zhaogong 王昭公. 1931. “Xingshi luoji zhi bengkui yu xin kexue de fangfalun zhi wancheng 形式邏輯之崩潰與新科學的方法論之完成 (The Decline of Formal Logic and Completion of a New Scientific Methodology).” Dushu zazhi 1 (2): 8-35.

Ye, Qing 葉青. 1933. “Dongde luoji shi keneng de! Da Zhang Dongsun jiaoshou 動的邏輯是可能的! 答張東荪教授 (A Dynamic Logic is Possible! An Answer to Professor Zhang Dongsun).” Xin Zhonghua 1 (23): 52-69.

- 1934. Zhang Dongsun zhexue pipan 張東蓀哲學批判 (A Critique of Zhang Dongsun's Philosophy). 2 Volumes. Shanghai: Xinken shudian.

—, ed. 1935a. Zhexue lunzhan 哲學論戰 (The Philosophical Polemic). Shanghai: Xinken shudian.

—, ed. 1935b. Heigeer - qi shengping qi zhexue jiqi yingxiang 黑格爾--- 其生 平其哲學及其影響 (Hegel一His Life, Philosophy and Influences). Shanghai: Xinken shudian.

—. 1936a. "Xingshi luoji yu bianzheng luoji 形式邏輯與辯證邏輯 (Formal Logic and Dialectical Logic). Yanjiu yu pipan 2 (2): 73-82.

—. 1936b. “Xingshi luoji yu bianzheng luoji 形式邏輯與辯證邏輯 (Formal Logic and Dialectical Logic)." Yanjiu yu pipan 2 (3): 49-54.

—.1937a. "Xingshi luoji yu bianzheng luoji 形式邏輯與辯證邏輯 (Formal Logic and Dialectical Logic).” Zhongshan wenhua jiaoyuguan jikan 4 (2): 663-79.

—. 1937b. Lunlixue wenti 論理學問題 (Problems of Logic). Shanghai: Zhenli chubanshe.

Zhang, Dongsun 張東荪. 1931. “Wo yi tantan bianzheng de weiwulun 我亦談談 辯證的唯物論 (I Am also Discussing Dialectical Materialism).” Dagong bao, September 18: 11. 
—. 1933. “Dongde luoji shi kenengde ma? 動的邏輯是可能的麼? (Is Dynamic Logic Possible?).” Xin Zhonghua 1 (18): 18-28.

- ed. 1934a. Weiwu bianzhengfa lunzhan 唯物辯證法論戰 (The Polemic on Materialist Dialectics). 2 Volumes. Beijing: Minyou shuju.

—.1934b. “Sixiang de luntan shang jige shimao wenti 思想的論壇上幾個時髦 問題 (A Few Fashionable Questions in the Forum of Ideas).” Xin Zhonghua 2 (10): 54-59; 2 (11): 56-59.

—. 1939. “Butong de luoji yu wenhua bing lun Zhongguo lixue 不同的邏輯與 文化並論中國理學 (Different Types of Logic and Culture-Discussed Together with Chinese Neo-Confucianism)." Yanjing xuebao 26: 2-39, 282-83. Zhou, Yunzhi 周云之, and Zhou Wen Ying 周文英. 1989. Zhongguo luojishi 中 國邏輯史 (The History of Chinese Logic), vol. 5: Xiandai juan 現代卷 (Modern Era). Lanzhou: Gansu renmin chubanshe.

Zhu, Baiying 祝百英 (Yiying 亦英). 1930a. “Junhenglü yu maodunlü 均衡率與 矛盾律 (Law of Equilibrium and Law of Contradiction)." Dongfang zazhi 29 (5): 47-51.

— . 1930b. “Renshilun zhong de xingshi lunli yu maodun lunli 認識論中的形 式論理與矛盾論理 (Formal Logic and Contradictory Logic in Epistemology)." Dongfang zazhi 29 (6): 11-15. 